\title{
Do mangrove forest restoration or rehabilitation activities return biodiversity to pre-impact levels?
}

\author{
Dominic A Andradi-Brown ${ }^{1 *}$, Caroline Howe ${ }^{2}$, Georgina M Mace ${ }^{2}$ and Andrew T Knight, 13
}

\begin{abstract}
Background: Mangrove forest restoration and rehabilitation programs are increasingly undertaken to re-establish ecosystem services in the context of community-based biodiversity conservation. Restoration is returning a habitat to the most natural condition, whereas rehabilitation often focuses on optimising ecosystem services alongside biodiversity. With many different restoration and rehabilitation objectives and techniques existing, it is difficult to assess the general effectiveness of restoration and rehabilitation on biodiversity and ecosystem services. This systematic review protocol presents a methodology that will be used to assess the impacts of mangrove forest restoration and rehabilitation on biodiversity and provisioning ecosystem services in a global context.

Methods: This review will assess studies that have undertaken biodiversity surveys of restored and rehabilitated mangrove forests by comparing them against suitable mature reference mangrove forests within the same region, or surveys prior to degradation of the forest. This review will investigate how the age and initial tree diversity of a restoration or rehabilitation activities determine the effectiveness of these initiatives. Taxa of commercial value to local communities will be assessed to identify whether rehabilitation for optimal ecosystem service provision is likely to conflict with the full restoration of mangrove forests.
\end{abstract}

Keywords: Mangroves, Tropical forest, Restoration, Rehabilitation, Biodiversity, Ecosystem services

\section{Background}

Mangrove forests are located in the tropical and subtropical areas at the boundary between the aquatic (normally marine or brackish) and the terrestrial environment [1]. Mangrove forests are biodiverse and provide a range of benefits (ecosystem services) mostly to local communities living in close proximity to the forests [2,3], as well as being closely coupled with other tropical marine environments such as coral reefs [4,5]. Despite their importance, mangrove forests have faced widespread destruction throughout the past century, with more than $25 \%$ of their global cover cleared between 1980 and 2000 [1] leading to fears they could be functionally extinct within 100 years [6]. In response to this many mangrove restoration and rehabilitation projects have been established [7].

Threats to mangrove forests vary regionally, but in many countries land conversion is causing the biggest losses [8].

\footnotetext{
* Correspondence: dominic.andradi-brown08@imperial.ac.uk

'Department of Life Sciences, Imperial College London, Silwood Park Campus, Buckhurst Road, Ascot, Berkshire SL5 7PY, UK

Full list of author information is available at the end of the article
}

Coastal land is often of high value creating large pressures for conversion for aquaculture and agriculture or infrastructure and development projects for facilities such as harbours and industries such as tourism $[8,9]$. In South-East Asia, mangrove clearance for shrimp aquaculture has become a major threat, increasing 20-30\% annually throughout the early 1990s, and is responsible for half of all mangrove clearance in the Philippines between 1951 and 1988 [10]. Large ponds that can be filled from and drained into the sea are created in areas cleared of mangroves, fragmenting the remaining mangrove forests, leading to the loss of many traditional livelihoods [11]. Forest overharvesting is a major threat in some areas, mainly caused by timber demand for firewood, charcoal and construction materials, but also for mangrove fruit, leaves, bark and roots which have a traditional medicinal role [12]. The impacts on biodiversity can be severe: for example, prolonged human extractive use combined with land conversion of mangroves in the Sundarbans, Bangladesh mangrove ecosystem has led to local terrestrial species extinctions [13] and fisheries decline $[14,15]$.

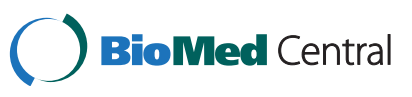


Biodiversity definitions, such as that adopted by the Parties to the Convention on Biological Diversity (CBD), tend to emphasise variability among and within species and the ecosystems they are part of. Biodiversity can therefore be considered at different levels, from genes through to whole ecosystems $[16,17]$, though in the context of mangrove restoration and rehabilitation programs it is normally assessed using species richness and forest structural assessments [18]. Mangrove forests tend to have low tree species richness compared to other tropical forests, with around 70 tree taxa found in mangroves of which a small subset have the potential to become dominant [19]. Despite this, mangroves dominated by different tree species can have similar and rich invertebrate communities, believed to be more influenced by salinity, tidal inundation and sediment composition than tree species diversity [20]. Niche partitioning studies have also been conducted in mangroves and associated intertidal mud flats to identify how such diverse communities can be maintained with a relatively homogenous input of organic materials and nutrients [21]. Disturbance through lightning strikes, hurricanes, frost damage, plant pathogens, wood boring insects and forest fires generate forest gaps [22], helping maintain heterogeneity in tree age.

Mangroves provide many ecosystem services, which can broadly be grouped following the four categories proposed by the Millennium Ecosystem Assessment [23] including provisioning (timber, fisheries), regulating (coastal protection, carbon storage), supporting (sediment stabilisation, primary production, nutrient cycling) and cultural (religious values, tourism and recreation) services (Table 1) $[2,24]$. At a global level there is increased awareness of the role of mangroves in carbon storage [25], both through timber but more importantly as 'blue carbon'- carbon resources stored underground in associated stable mangrove sediment, which can be greater than that within the standing mangrove forest [26].

Quantifying the amount of an ecosystem service is difficult, so metrics often use underpinning biodiversity as a proxy. The definition of biodiversity emphasises variability, yet many ecosystem services depend on abundance and traits of several dominant species rather than overall biodiversity $[17,38]$. While additional species in a community often may increase ecosystem resilience [39], ecosystem properties can often be maintained despite species loss due to functional redundancy or little contribution to the process from the species [40]. The focus on abundance becomes clear when considering some metrics used to assess the amount of an ecosystem service (see Table 1). Assessing the abundance or biomass of key taxa can therefore give an indication of service levels. For example, consider a provisioning ecosystem service such as crab harvesting for food in South-East Asian and Pacific mangrove forests [28]. Of the many species of crab found within mangrove forests only a few species are suitable for harvesting (e.g. Scylla serrata), so the biomass of these few species give a better indication of food provision than the overall crab species richness within the forest.

Recent recognition of the importance of mangrove forests has led to widespread efforts to restore or rehabilitate deforested mangrove areas, with many of these projects hoping to combine re-establishing ecosystem services for local communities benefits with biodiversity conservation [7]. With a diverse range of techniques available

Table 1 Ecosystem services and example assessment metrics reported from mangrove forests

\begin{tabular}{|c|c|c|c|c|}
\hline $\begin{array}{l}\text { Ecosystem } \\
\text { service type }\end{array}$ & Examples & $\begin{array}{l}\text { Biodiversity or abiotic } \\
\text { component responsible }\end{array}$ & Example assessment metrics & $\begin{array}{l}\text { Example } \\
\text { studies }\end{array}$ \\
\hline \multirow[t]{2}{*}{ Provisioning } & Timber & Tree species & Stand density, stem diameter, tree height & {$[27]$} \\
\hline & Fisheries & $\begin{array}{l}\text { Fish and invertebrate } \\
\text { species }\end{array}$ & Abundance and biomass of relevant species & {$[28,29]$} \\
\hline \multirow[t]{2}{*}{ Regulating } & Coastal protection & Tree species & $\begin{array}{l}\text { Mangrove area, tree density and structural } \\
\text { complexity }\end{array}$ & {$[30,31]$} \\
\hline & Carbon storage & Sediment, Tree species & $\begin{array}{l}\text { Sediment depth, sediment carbon content, } \\
\text { tree biomass }\end{array}$ & {$[32]$} \\
\hline \multirow[t]{3}{*}{ Supporting } & $\begin{array}{l}\text { Erosion control and sediment } \\
\text { stabilisation (land expansion) }\end{array}$ & Tree species & $\begin{array}{l}\text { Forest age, density, form and structural complexity } \\
\text { of dominant tree species }\end{array}$ & {$[33,34]$} \\
\hline & Primary production & Tree species & Leaf litter, tree biomass gain & {$[35]$} \\
\hline & Nutrient cycling & $\begin{array}{l}\text { Whole biotic community } \\
\text { and sediment }\end{array}$ & Leaf litter biomass & {$[36]$} \\
\hline \multirow[t]{2}{*}{ Cultural } & Religious values & Unclear & Unclear & {$[24]$} \\
\hline & Tourism and recreation & Highly variable & $\begin{array}{l}\text { Species richness and abundance of charismatic } \\
\text { species }\end{array}$ & {$[37]$} \\
\hline
\end{tabular}


for restoration and rehabilitation, it is important to ensure that a clear objective exists [41]. Goals of mangrove restoration or rehabilitation often include: conservation, coastal protection, timber production forests or mixed use forests for high sustainable yields [18,42]. Restoration is defined by the Society for Ecological Restoration [43] as 'the process of assisting the recovery of an ecosystem that has been degraded, damaged, or destroyed, whereas rehabilitation focuses on 'reparation of ecosystem processes, productivity and services'. The goal of restoration is to make structural or functional changes to an ecosystem to return it to original condition (biotic community structure and species composition), while rehabilitation emphasises modifying ecosystem structural or functional characteristics to achieve a desired outcome. The difference between these two definitions highlights a potential conflict in objectives. Mangrove systems can be restored or rehabilitated at different scales through a suite of different methods, from natural regeneration through to direct planting of single or mixed species plantations [18]. Ensuring the correct hydrological regime by changing river and coastal water management regimes if required maybe essential for effectiveness, and often is enough for natural regeneration to occur [44].

Early mangrove rehabilitation programs focused on establishing forest cover often for timber value and coastal protection without directly considering further biodiversity components, such as tree or structural diversity [41]. Plantations in mangroves are often monocultures due to ease of planting or for silviculture, enabling harvesting at the same time [44]. While there has been a slight increase in multi-species plantations for restoration since the early 1980s, even when true ecosystem restoration is clearly the objective, fewer mangrove tree species are normally used in initial forest establishment and any subsequent supplementary planting than are found in natural forests [44]. Many mangrove restoration and rehabilitation projects are conducted through integrated conservation and development projects [45] or community based natural resource management programs [46], engaging local communities and focusing on ecosystem services provided by mangroves in part to try to establish protection of biodiversity through sustainable use. Often, projects conducted in this context labelled as mangrove restoration are actually rehabilitation, as they seek to establish mangrove forests that either maximise benefits to people or try to balance benefits to people and biodiversity conservation without directly aiming to recreate the most natural biotic community possible.

There is currently mixed evidence for the effectiveness of mangrove restoration and rehabilitation projects, in part due to a lack of objective goal-setting and a lack of will to fund full ecological restoration favouring other goals $[41,47]$. A previous study found rehabilitated mangrove forests had higher crab abundances than natural mangroves [48], but that the crab community was more similar to natural forests than the previous bare mud flat. In another study, planting technique during rehabilitation was found to affect epibiotic communities, through varying root surface area and so changing algal diversity and epibiotic community biomass and structure [49]. When considering ecosystem services more directly, a study found local people in Kenya used natural mangroves in preference and considered them more valuable than replanted forests for most ecosystem services [24]. The only exception was building materials, as replanted mangrove plantations were considered to contain more suitable timber for cutting wooden poles of high quality. This raises the concern that restored and rehabilitated forests may not contain biodiversity and associated ecosystem service benefits at the levels found in natural forests. This issue is not new, and a recent global study incorporating data from 89 studies across six different broadly defined biomes found restoration increased biodiversity by $44 \%$ and ecosystem services by $25 \%$ relative to levels prior to restoration, but despite this increase both biodiversity and ecosystem service provision remained lower than natural ecosystems [50].

Mangrove restoration and rehabilitation, however, could potentially be more effective than restoration or rehabilitation in other ecosystems, as natural mangrove forests have low tree species richness compared to other tropical forests and are often dominated by a single species or even exist as single species stands [51]. Mangrove leaf litter has an important role alongside imported phytodetritus from surrounding areas in decomposition and nutrient cycling between the mangrove biotic and abiotic components as well as linking mangrove vegetation to fauna [52]. Studies of crabs in isolation suggest different crab species feed preferentially on the same species of leaves [21], suggesting that while many rehabilitated forests may not have maximal tree species richness, they may still support many other dependent ecological communities.

Despite the proliferation of projects aiming to restore and rehabilitate mangroves there is currently very little evaluation of their effectiveness. A recent narrative review by Bosire et al. [7] investigated functionality of restored mangroves. While they identified some trends they also found contradictory studies documenting invertebrate species abundance and diveristy. However, the review only used a subset of the available literature on the topic, of which the majority was published in peer-review journals or FAO reports. With so much recent attention being given to mangrove loss [6], payment for ecosystem services schemes often with a focus on carbon [53], and community based conservation [46] it is important to systematically and quantitatively evaluate the effectiveness of mangrove restoration and rehabilitation schemes 
using all available evidence from a range of sources. This project seeks to understand the effectiveness of mangrove restoration and rehabilitation for biodiversity conservation and associated provisioning ecosystem services through a systematic review comparing restored and rehabilitated mangrove forests with reference mature mangrove systems globally across a range of taxonomic groups. Uniquely using this approach will minimise bias in the studies included and allow quantitative synthesis of results, giving indications of magnitude of differences between restored or rehabilitated mangroves and reference sites.

\section{Objective of the review Primary question}

Do mangrove forest restoration and rehabilitation activities return biodiversity to pre-impact levels? This can be broken into components as shown in Table 2.

Mangrove restoration and rehabilitation sites are considered as any sites that have suffered large scale anthropogenic degradation resulting in the loss of mature tree canopy cover and subsequently through a change in management begun to establish new tree canopy cover. Reference mangrove forests are mature mangrove forests composed of native tree species which have never been subjected to major anthropogenic impacts and represent as closely as possible the biodiversity of mangrove forests in the region. Alternatively the reference could be the restored or rehabilitated mangrove surveyed prior to first impact.

\section{Secondary questions}

Are provisioning ecosystem services restored during mangrove restoration or rehabilitation?

Does the success of mangrove restoration and rehabilitation for biodiversity and ecosystem services vary in relation to taxa or service types?

Subgroups for taxa will be defined at family, genus and species level as well as by trophic group. Subsequent analysis will be conducted at the level most appropriate once data extraction is complete. This will be determined by the resolution of the taxonomic data provided within studies and will be the lowest taxonomic level at which there is a sufficient sample size for metaanalysis to be conducted.
Subgroups for ecosystem services will be grouped following the broad categories of ecosystem service: provisioning, regulating, supporting and cultural based on the Millennium Ecosystem Assessment definitions [23]. Additionally, if sufficient data allows, provisioning services will be subdivided into food, water, timber etc. as appropriate.

\section{Methods}

\section{Searches}

Searches will be limited to English. Non-English language articles providing a published title and abstract in English will be included in the review, with the full text being translated if required. Non-English language articles without an English title and abstract will be excluded from the review. Searches will not intentionally be restricted by year, however database access will be limited to certain years by institutional subscriptions (see below for details).

\section{Databases}

We aim to search the following databases:

- ISI Web of Knowledge platform - http:// isiknowledge.com

○ Web of Science (1970-present)

- BIOSIS Citation Index (1969-2008)

o Current Contents Connect (1998- present)

o CABI: CAB Abstracts (1973- present)

- MEDLINE (1950- present)

○ Zoological Record (1864- present)

- Science Direct - http://www.sciencedirect.com (all years)

- JSTOR - http://www.jstor.org (all years)

- Index to Theses Online - http://www.theses.com (all years)

- Scopus - http://www.scopus.com

- AGRICOLA - http://agricola.nal.usda.gov (all years)

- Aquatic Sciences \& Fisheries Abstracts - http:// search.proquest.com/asfa (all years)

- Environmental Sciences \& Pollution Management http://search.proquest.com/espm (all years)

All relevant database records will be downloaded with abstracts (where possible) and stored in an EndNote library.

Table 2 Structure of the primary systematic review question

\begin{tabular}{llll}
\hline $\begin{array}{l}\text { Subject } \\
\text { (population) }\end{array}$ & Intervention & Comparator & Outcome \\
\hline Mangroves & Restoration or rehabilitation & $\begin{array}{l}\text { Restored or rehabilitated mangrove compared } \\
\text { with adjacent reference mangroves. Restored or } \\
\text { rehabilitated mangrove surveyed prior to impact } \\
\text { and after restoration. }\end{array}$ & $\begin{array}{l}\text { Difference in biodiversity or abundance measure. } \\
\text { Difference in ecosystem service measure. }\end{array}$ \\
\hline
\end{tabular}




\section{Specialist sources}

The websites of the following organisations working on mangrove related projects will be searched. Relevant studies and references contained within will be identified. Links from these websites will be followed once, to any partner organisation that potentially may have studies available. The partner organisation website will then be searched for relevant studies or references.

- Bird Life International Mangrove Alliance http:// www.birdlife.org/mangrove-alliance

- Center for International Forestry Research http:// www.cifor.org/

- GLOMIS - Global Mangrove Database \& Information System http://www.glomis.com

- International Society for Mangrove Ecosystems http://www.mangrove.or.jp

- MangroveRestoration.com http://www. mangroverestoration.com

- Mangrove Action Project http://www. mangroveactionproject.org

- RAMSAR http://www.ramsar.org

- Society for Ecological Restoration http://www.ser.org

- Society for Wetlands Scientists http://www.sws.org

- UN Food and Agriculture Organization http://www. fao.org

- USAID http://dec.usaid.gov

- Wetlands International http://www.wetlands.org

- World Fish Centre http://www.worldfishcenter.org

\section{Search engines}

An Internet search will be carried out using the following search engines:

- Google Scholar - http://scholar.google.co.uk

- Scirus - http://www.scirus.com

Search will be limited to Word and/or PDF documents when possible. The first 50 Word and PDF document hits will be examined and references contained within articles viewed at full text will be searched.

\section{Search terms}

Review scoping was conducted to guide the construction of this protocol. The search terms were developed following an iterative process. The search string was developed using ISI Web of Knowledge and trialled against a test library. The test library consisted of 12 studies containing relevant data to the systematic review and identified by the review team from existing publications reference lists (Additional file 1). The proportion of studies in the test library identified by each search string was recorded as the search terms were refined (Additional file 2).
The final search terms to be used are as follows (though these may be simplified when searching databases that do not allow Boolean operators or wildcards):

Mangrove* OR "Inter-tidal forest" OR "Intertidal forest" OR Rhizophora*

\section{AND \\ Reforest* OR Restor* OR Replant* OR Secondary OR Plantation* OR Planted OR Regenerat* OR Rehabilitat* OR Stand}

AND

*divers* OR Communit" OR "Yield table ${ }^{* *}$

\section{Study inclusion criteria}

In order to only select relevant studies the following inclusion criteria will be applied sequentially in three stages: 1 ) by title, 2) by abstract and 3) by full text. If there is uncertainty in relevance of an article it will be put through to the next stage. Citations will be stored in EndNote (version X5, http://www.endnote.com) and EPPI-Reviewer (version 4, http://eppi.ioe.ac.uk/cms/er4) at each stage.

Study inclusion criteria for title and abstract screening:

1. Relevant subject: Mangrove forest

2. Relevant intervention: Site where mangrove forests have been established either through direct plantations or protection to allow natural regeneration.

3. Relevant outcome: Indication that a component of species biodiversity, abundance, or directly biodiversity related ecosystem service measure is assessed/measured.

4. Relevant comparator: Indication that study attempts to evaluate the quality/success of the mangrove restoration. If comparators are specified then a reference mature mangrove forest for comparison or data on original mangrove forest structure pre-impact and post restoration.

During abstract screening it is not expected that comparators will be explicitly stated in abstracts, however, from preliminary search testing all relevant studies stated that they aimed to evaluate restoration success in their abstracts, with the majority specifically stating the existence of a comparator.

Study inclusion criteria for full text screening:

1. Relevant subject: Mangrove forest

2. Relevant intervention: Study must include a site where mangrove forest has been established (either 
through: direct plantations, protection of an area allowing regeneration, natural regeneration combined with supplementary planting or altering environmental conditions to enable a mangrove forest to establish) where prior to the establishment/colonisation event there were not intact mangrove forests.

3. Relevant comparator: Restored mangrove compared with adjacent reference mangroves (mature mangrove forest(s) composed of native tree species which have never been subjected to major anthropogenic impacts and represent as closely as possible the biodiversity of mangrove forests in the region); or the restored mangrove was surveyed prior to first impact and after restoration and the surveys compared.

4. Relevant outcome: Empirical data contained for species biodiversity, abundance or biomass, or a difference in ecosystem service measure in both the intervention and the comparator. Studies must report mean, variance measure (variance, $\mathrm{SD}, \mathrm{SE}$, stated confidence intervals) and the sample size for both the intervention and the comparator.

Two researchers will assess a random 100 citations, applying the inclusion criteria at title and abstract level. Agreement between the two reviewers will be measured by kappa analysis, where a value of 0.6 or greater indicates good agreement [54]. If kappa is less than 0.6, differences will be discussed and clarified and the inclusion criteria modified if required. One reviewer will apply the agreed inclusion criteria to all remaining articles.

\section{Potential effect modifiers and reasons for heterogeneity}

Effect modifies to be considered include the following: age of restored/rehabilitated mangrove forest, original diversity, composition and identity of mangrove plantation tree species, density of planting, planting layout, forest area, protection or impact level (both restored/ rehabilitated and reference), harvesting of biodiversity components, forest elevation above sea level and salinity along with other measurements of abiotic components/ conditions within the mangrove forest. Additional possible effect modifiers reported in the studies will be recorded with and a decision on whether to include these made once it become clear how many studies provide that information.

\section{Study quality assessment}

While Before After Control Impact (BACI) studies are considered most robust, most studies are expected to contain control-impact (CI) quantitative assessments of biodiversity and/or ecosystem services in restored mangroves and a reference mangrove system. A detailed study critical appraisal methodology will be developed after the articles for inclusion in the review have been identified involving recording the spatial replication within and environmental similarity between the restoration and the comparator site. Studies will be classified as 'high', 'medium' or 'low' quality based these criteria to broadly define susceptibility to bias. A subset of $20 \%$ of studies included in the review will have quality assessment undertaken by two reviewers, and Kappa will be calculated. If Kappa is less than 0.6 the critical appraisal methodology will be clarified though consensus. One reviewer will then complete critical appraisal for all articles.

\section{Data extraction strategy}

Data will be extracted into a spreadsheet, recording outcomes, methodology, number of replicates and age of resorted mangrove forest along with all the above mentioned effect modifiers. The template spreadsheet for data extraction (Additional file 3) was developed during trial data extraction of studies identified during search term testing and provides a clear framework for extraction ensuring repeatability and efficiency. The template also provides space for any other relevant factors identified while reading an article at full text to be included. If any studies are found to be missing key relevant data an attempt to contact the authors will be made.

\section{Data synthesis and presentation}

From trial searches and data extraction we are confident effect sizes can be calculated and a meta-analysis conducted. For abundance and biomass data we plan to use the natural logarithm transformed response ratio $(\ln R)$ as an effect size, the natural logarithm of the ratio of mean abundance or biomass from the restoration or rehabilitation and the reference site [55]:

$$
\ln R=\ln \left(\frac{\bar{X}_{\text {REST }}}{\bar{X}_{R E F}}\right)
$$

Where $\bar{X}_{R E S T}$ and $\bar{X}_{R E F}$ represent the mean abundance or biomass at the restoration or rehabilitation site and the mean abundance or biomass at the reference site respectively. Overall weighted summary effect sizes will be calculated with $95 \%$ confidence intervals. As many of the differences in observed effects may be caused by differences in restoration and rehabilitation implementation, a random effects model will be used during meta-analysis. For abundance and biomass this will use Eq. 2 [56], where $\operatorname{Ln} R_{i}$ equals the effect size, 
$W_{i}$ equals the weighting and $k$ equals the number of studies.

$$
\overline{\ln R}=\frac{\sum_{i=1}^{k} W_{i} \ln R_{i}}{\sum_{i=1}^{k} W_{i}}
$$

Abundance and biomass studies will be weighted by the inverse of the variance (Eq. 3) [55], where $\bar{X}$ equals the mean abundance or biomass, $s$ equals the standard deviation of that mean and $n$ equals the number of replicates.

$$
V_{L n R}=\frac{s_{R E S T}^{2}}{n_{R E S T}\left(\bar{X}_{R E S T}\right)^{2}}+\frac{s_{R E F}^{2}}{n_{R E F}\left(\bar{X}_{R E F}\right)^{2}}
$$

Mixed effects models will be used to test the importance of effect modifiers. Sub-group analysis will also be run to investigate the effects of different taxonomic groups and ecosystem service types to address the proposed secondary questions.

It is expected that insufficient suitable studies will be identified to allow meta-analysis for all taxonomic groups or ecosystem services types. If this is the case, the outcomes for these taxonomic groups or ecosystem service types will be summarised in tables.

\section{Additional files}

\section{Additional file 1: Test library of papers.}

Additional file 2: Table of search terms trialled against number of hits from Web of Knowledge.

Additional file 3: Template data extraction spreadsheet.

\section{Competing interests}

The authors declare that they have no competing interests.

\section{Authors' contributions}

$D A B, C H, G M$ and $A K$ developed the review question. DAB conducted the pilot research. DAB wrote the protocol with support from $\mathrm{CH}, \mathrm{GM}$ and $\mathrm{AK}$. All authors read and approved the final manuscript.

\section{Acknowledgments}

ATK acknowledges the support of the ARC Centre of Excellence in Environmental Decisions at The University of Queensland, Australia. The authors would like to thank two anonymous reviewers and the journal editor for valuable comments which improved this protocol.

\section{Author details \\ 'Department of Life Sciences, Imperial College London, Silwood Park Campus, Buckhurst Road, Ascot, Berkshire SL5 7PY, UK. ${ }^{2}$ Centre for Biodiversity and Environment Research, Department of Genetics, Evolution and Environment, University College London, London WC1E 6BT, UK . ${ }^{3}$ Department of Botany, Nelson Mandela Metropolitan University, P.O. Box 77000, Port Elizabeth 6031, South Africa.}

Received: 19 June 2013 Accepted: 17 September 2013 Published: 28 October 2013

\section{References}

1. Hogarth P: The biology of mangroves and seagrasses. 2nd edition. New York: Oxford University Press; 2007
2. Barbier EB, Hacker SD, Kennedy C, Koch EW, Stier AC, Silliman BR: The value of estuarine and coastal ecosystem services. Ecol Monogr 2011, 81:169-193.

3. Vo QT, Kuenzer C, Vo QM, Moder F, Oppelt N: Review of valuation methods for mangrove ecosystem services. Ecol Indic 2012, 23:431-446.

4. Demopoulos AWJ, Cormier N, Ewel KC, Fry B: Use of multiple chemical tracers to define habitat use of Indo-Pacific mangrove crab, Scylla serrata (Decapoda: Portunidae). Estuar Coast Shelf Sci 2008, 31:371-381.

5. Mumby PJ, Hastings A: The impact of ecosystem connectivity on coral reef resilience. J Appl Ecol 2008, 45:854-862.

6. Duke NC, Meynecke JO, Dittmann S, Ellison AM, Anger K, Berger U, Cannicci S, Diele K, Ewel KC, Field CD, Koedam N, Lee SY, Marchand C, Nordhaus I, Dahdouh-Guebas F: A world without mangroves? Science 2007, 317:41-42.

7. Bosire JO, Dahdouh-Guebas F, Walton M, Crona BI, Lewis RR, Field C, Kairo JG, Koedam N: Functionality of restored mangroves: a review. Aquat Bot 2008, 89:251-259.

8. Valiela I, Bowen JL, York JK: Mangrove forests: One of the World's threatened major tropical environments. Bioscience 2001, 51:807.

9. Alongi DM: Present state and future of the world's mangrove forests. Environ Conserv 2002, 29:331-349.

10. Primavera JH: Socio-economic impacts of shrimp culture. Aquac Research 1997, 28:815-827.

11. Gunawardena M, Rowan JS: Economic valuation of a mangrove ecosystem threatened by shrimp aquaculture in Sri Lanka. Environ Manage 2005, 36:535-550.

12. Warren-Rhodes K, Schwarz A-M, Boyle LN, Albert J, Agalo SS, Warren R, Bana A, Paul C, Kodosiku R, Bosma W, Yee D, Rönnbäck P, Crona B, Duke N: Mangrove ecosystem services and the potential for carbon revenue programmes in Solomon Islands. Environ Conserv 2011, 38:485-496.

13. Seidenstlcker J, Hai A: The sundarbans wildlife management plan: conservation in the Bangladesh coastal zone. Gland, Switzerland: International Union for Conservation of Nature and Natural Resources; 1983.

14. Deb AK: Fake blue revolution: environmental and socio-economic impacts of shrimp culture in the coastal areas of Bangladesh. Ocean \& Coastal Management 1998, 41:63-88.

15. Islam MS, Haque M: The mangrove-based coastal and nearshore fisheries of Bangladesh: ecology, exploitation and management. Rev Fish Biol Fish 2004, 14:153-180.

16. OTA: Technologies to maintain biological diversity. Washington, DC: U.S: Congress, Office of Technology Assessment, U.S. Government Printing Office; 1987.

17. Mace GM, Norris K, Fitter AH: Biodiversity and ecosystem services: a multilayered relationship. Trends Ecol Evol 2012, 27:19-26.

18. Field C: Rehabilitation of mangrove ecosystems: an overview. Mar Pollut Bull 1999, 37:383-392.

19. Duke NC, Ball MC, Ellison JC: Factors influencing biodiversity and distributional gradients in mangroves. Glob Ecol Biogeogr Lett 1998, 7:27-47.

20. Michael Gee J, Somerfield PJ: Do mangrove diversity and leaf litter decay promote meiofaunal diversity? J Exp Mar Biol Ecol 1997, 218:13-33.

21. Todd PA, Yeo DCJ, Ya BP: Feeding ecology of two species of Perisesarma (Crustacea: Decapoda: Brachyura: Sesarmidae) in Mandai mangroves, Singapore. J Crustac Biol 2008, 28:480-484.

22. Duke NC: Gap creation and regenerative processes driving diversity and structure of mangrove ecosystems. Wetlands Ecol Manage 2001, 9:267-279.

23. Millennium ecosystem assessment. Ecosystems and human well-being: biodiversity synthesis. [http://www.unep.org/maweb/documents/ document.354.aspx.pdf]

24. Rönnbäck P, Crona B, Ingwall L: The return of ecosystem goods and services in replanted mangrove forests: perspectives from local communities in Kenya. Environ Conserv 2007, 34:313-324.

25. Mcleod E, Chmura GL, Bouillon S, Salm R, Björk M, Duarte CM, Lovelock CE, Schlesinger WH, Silliman BR: A blueprint for blue carbon: toward an improved understanding of the role of vegetated coastal habitats in sequestering CO 2. Front Ecol Environ 2011, 9:552-560.

26. Pendleton L, Donato DC, Murray BC, Crooks S, Jenkins WA, Sifleet S, Craft C, Fourqurean JW, Kauffman JB, Marbà N, Megonigal P, Pidgeon E, Herr D, Gordon D, Baldera A: Estimating global "blue carbon" emissions from conversion and degradation of vegetated coastal ecosystems. PLOS ONE 2012, 7:e43542.

27. Kairo JG, Lang'at JKS, Dahdouh-Guebas F, Bosire J, Karachi M: Structural development and productivity of replanted mangrove plantations in Kenya. Forest Ecol Manag 2008, 255:2670-2677. 
28. Bonine KM, Bjorkstedt EP, Ewel KC, Palik M: Population characteristics of the mangrove crab Scylla serrata (Decapoda: Portunidae) in Kosrae, Federated States of Micronesia: effects of harvest and implications for management. Pac Sci 2008, 62:1-19.

29. Rönnbäck P: The ecological basis for economic value of seafood production supported by mangrove ecosystems. Ecol Econ 1999, 29:235-252.

30. Das S, Vincent JR: Mangroves protected villages and reduced death toll during Indian super cyclone. Proc Natl Acad Sci 2009, 106:7357-7360.

31. Mazda Y, Magi M, Kogo M, Hong PN: Mangroves as a coastal protection from waves in the tong king delta, Vietnam. Mangrove Salt Marshes 1997, 1:127-135.

32. Donato DC, Kauffman JB, Murdiyarso D, Kurnianto S, Stidham M, Kanninen M: Mangroves among the most carbon-rich forests in the tropics. Nat Geosci 2011, 4:293-297.

33. Carlton JM: Land-building and stabilization by mangroves. Environ Conserv 1974, 1:285-294.

34. Alongi DM, Pfitzner J, Trott LA, Tirendi F, Dixon P, Klumpp DW: Rapid sediment accumulation and microbial mineralization in forests of the mangrove Kandelia candel in the Jiulongjiang Estuary, China. Estuar Coast Shelf Sci 2005, 63:605-618.

35. Amarasinghe MD, Balasubramaniam S: Net primary productivity of two mangrove forest stands on the northwestern coast of Sri Lanka. Hydrobiologia 1992, 247:37-47.

36. Twilley RW, Lugo AE, Patterson-Zucca C: Litter Production and Turnover in Basin Mangrove Forests in Southwest Florida. Ecology 1986, 67:670.

37. Bacon PR: Use of wetlands for tourism in the insular Caribbean. Ann Tour Res 1987, 14:104-117.

38. Cardinale BJ, Duffy JE, Gonzalez A, Hooper DU, Perrings C, Venail P, Narwani A, Mace GM, Tilman D, Wardle DA, Kinzig AP, Daily GC, Loreau M, Grace JB, Larigauderie A, Srivastava DS, Naeem S: Biodiversity loss and its impact on humanity. Nature 2012, 486:59-67.

39. Elmqvist T, Folke C, Nystrom M, Peterson G, Bengtsson J, Walker B, Norberg J: Response diversity, ecosystem change, and resilience. Front Ecol Environ 2003, 1:488-494.

40. Hooper DU, Chapin FS III, Ewel JJ, Hector A, Inchausti P, Lavorel S, Lawton JH, Lodge DM, Loreau M, Naeem S, Schmid B, Setälä H, Symstad AJ, Vandermeer J, Wardle DA: Effects of biodiversity on ecosystem functioning: a consensus of current knowledge. Ecol Monogr 2005, 75:3-35.

41. Lewis RR III: Ecologically based goal setting in mangrove forest and tidal marsh restoration. Ecol Eng 2000, 15:191-198.

42. Lewis RR III: Methods and Criteria for Successful Mangrove Forest Restoration. In Coastal Wetlands: An integrated ecosystem approach. Edited by Perillo GME, Wolanski E, Cahoon DR, Brinson MM. Oxford: Elsevier; 2009:787-800.

43. Society for Ecological Restoration International Science Policy Working Group: Society for ecological restoration international science \& policy working group. 2nd edition. The SER International Primer on Ecological Restoration; 2004. www.ser.org \& Tucson: Society for Ecological Restoration International.

44. Ellison AM: Mangrove restoration: do we know enough? Restor Ecology 2000, 8:219-229.

45. Smith $\mathrm{AH}$, Berkes $\mathrm{F}$ : Community-based use of mangrove resources in St. Lucia. Int J Environ Stud 1993, 43:123-131.

46. Datta D, Chattopadhyay RN, Guha P: Community based mangrove management: a review on status and sustainability. J Environ Manage 2012, 107:84-95.

47. Lewis RR III: Ecological engineering for successful management and restoration of mangrove forests. Ecol Eng 2005, 24:403-418.

48. Bosire JO, Dahdouh-Guebas F, Kairo JG, Cannicci S, Koedam N: Spatial variations in macrobenthic fauna recolonisation in a tropical mangrove bay. Biodivers Conserv 2004, 13:1059-1074.

49. Crona Bl, Holmgren S, Rönnbäck P: Re-establishment of epibiotic communities in reforested mangroves of Gazi Bay, Kenya. Wetlands Ecol Manage 2006, 14:527-538.

50. Benayas JMR, Newton AC, Diaz A, Bullock JM: Enhancement of biodiversity and ecosystem services by ecological restoration: a meta-analysis. Science 2009, 325:1121-1124.

51. Ashton EC, Hogarth PJ, Macintosh DJ: A comparison of brachyuran crab community structure at four mangrove locations under different management systems along the Melaka Straits-Andaman Sea Coast of Malaysia and Thailand. Estuaries 2003, 26:1461-1471.
52. Bouillon S, Koedam N, Raman A, Dehairs F: Primary producers sustaining macro-invertebrate communities in intertidal mangrove forests. Oecologia 2002, 130:441-448.

53. Lau WWY: Beyond carbon: conceptualizing payments for ecosystem services in blue forests on carbon and other marine and coastal ecosystem services. Ocean \& Coastal Management 2013, 83:5-14

54. Landis JR, Koch GG: The measurement of observer agreement for categorical data. Biometrics 1977, 33:159-174

55. Hedges LV, Gurevitch J, Curtis PS: The meta-analysis of response ratios in experimental ecology. Ecology 1999, 80:1150-1156.

56. Borenstein M, Hedges LV, Higgins JPT, Rothstein HR: Introduction to meta-analysis. John Wiley \& Sons, Ltd: Chichester, UK; 2009

doi:10.1186/2047-2382-2-20

Cite this article as: Andradi-Brown et al:: Do mangrove forest restoration or rehabilitation activities return biodiversity to pre-impact levels? Environmental Evidence 2013 2:20.

\section{Submit your next manuscript to BioMed Central and take full advantage of:}

- Convenient online submission

- Thorough peer review

- No space constraints or color figure charges

- Immediate publication on acceptance

- Inclusion in PubMed, CAS, Scopus and Google Scholar

- Research which is freely available for redistribution 